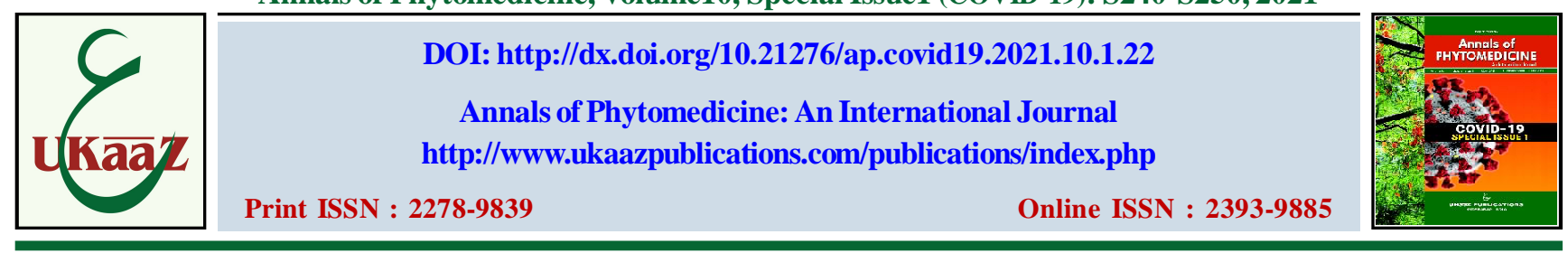

\title{
Role of functional food components in COVID-19 pandemic: A review
}

\author{
Hamid, Abhimanyu Thakur ${ }^{\star}$ and N.S. Thakur
}

Department of Food Science and Technology, Dr Yashwant Singh Parmar University of Horticulture and Forestry, Nauni, Solan-173230, Himachal Pradesh, India

\section{Article Info}

\section{Article history}

Received 3 May 2021

Revised 20 June 2021

Accepted 21 June 2021

Published Online 30 June 2021

Keywords
Corona
COVID
Functional foods
Immunity
Micronutrients
Nutrition

\section{Introduction}

Coronavirus disease 2019 (COVID-19) caused by a novel coronavirus, named severe acute respiratory syndrome coronavirus 2 (SARS-CoV2), originated in the city of Wuhan, Hubei Province, Central China and has spread quickly to many countries till date (Li et al., 2020a). The name coronavirus was derived from the Latin word "corona" which means "crown" depicting the crown-like structure of the viral particle. COVID-19 has posed a high risk to global public health and the symptoms include fever, tiredness, dry cough whereas, in severe cases, it can be even fatal (Lei et al., 2020).

Nutrition plays an important role in improving well-being and can mitigate the risk and morbidity associated with coronavirus disease 2019 (COVID-19) which is caused by the severe acute respiratory syndrome coronavirus 2 (Coelho-Ravagnani et al., 2020). Nutritional status is a crucial factor for optimal prognosis in SARS-CoV-2 infected individuals and can determine the clinical severity of COVID-19 (Laviano et al., 2020). Zhang and Liu (2020) have suggested dietary supplementation as a treatment option for COVID-19 patients and as preventive therapy against lung infection. The dietary supplementation includes selected vitamins like vitamin A, B, C, and $\mathrm{D}$; minerals like selenium, zinc, and iron; and omega-3 fatty acids.

The various functional foods have immune boosting properties and the healthy immune system plays an important role in maintaining human health whereas nutrition plays an important role in the

\footnotetext{
Corresponding author: Dr. Abhimanyu Thakur Assistant Professor, Department of Food Science and Technology, Dr. Yashwant Singh Parmar University of Horticulture and Forestry, Nauni, Solan-173230, Himachal Pradesh, India

E-mail: abhimanyuthakurprashar@gmail.com Tel.: +91-9882239719
}

Copyright () 2021 Ukaaz Publications. All rights reserved.

Email: ukaaz@yahoo.com; Website: www.ukaazpublications.com modulation of immune function (Thakur et al., 2019). Functional foods enhance the immune system capacity leading towards the prevention and control of pathogenic viral infections. The various components in functional foods and nutraceuticals contain various immune-boosting components like polyphenols, terpenoids, flavonoids, alkaloids, sterols, pigments, unsaturated fatty-acids, micronutrient, vitamins and minerals (Alkhatib, 2020). During COVID-19 pandemic, it has been reported that the mortality rate was higher among the patients who were having one or more chronic diseases. The chronic diseases weaken the immune system and increase the susceptibility of the individual towards COVID-19 like in elderly people. So, various functional foods and their bioactive compounds can be utilised to boost our immune system which further help in combating viral diseases including COVID-19 (Butler et al., 2020; Martirosyan, 2020). In present review, the role of various functional food components in immune system and their role in COVID-19 prevention and treatment have been discussed further.

\section{Behaviour of coronavirus}

Coronaviruses (CoVs) belongs to the family Coronaviridae, subfamily Orthocoronavirinae and order Nidovirales. The four genera within the subfamily, Orthocoronavirinae are Alpha coronavirus $(\alpha-\mathrm{CoV})$, Beta coronavirus $(\beta-\mathrm{CoV})$, Gamma coronavirus $(\gamma-\mathrm{CoV})$ and Delta coronavirus $(\delta-\mathrm{CoV})$. The important four structural proteins are essential for SARS-CoV-2 assembly and infection which are, namely; spike surface glycoprotein, the membrane protein, the envelope protein and the nucleocapsid protein (Yang and Leibowitz, 2015; Banerjee et al., 2019; Li et al., 2020a). The virus infecting humans (SARS-CoV-2) is the seventh member in the family of CoVs. A wide range of upper respiratory tract infections like common cold is caused by four human CoVs (HCoV-229E, HCoV-NL63, HCoVOC43 and HCoV-HKU1), whereas atypical pneumonia is caused by SARS-CoV 
and MERS-CoV (Li et al., 2020a). Morphologically, corona viruses have non-segmented positive-sense, single-stranded ribonucleic acid (ssRNA) enveloped by structural proteins and surface is associated with the club-shaped protein (spikes) which is observed under the 2-D transmission electron microscopy (Fehr and Perlman, 2015; Singh et al., 2020).

During COVID-19 infection process, the virus particles spread through the respiratory tract which further infect the surrounding uninfected cells (Seyed et al., 2020). After entering into alveolar epithelial cells, there is rapid replication of virus which triggers a strong immune response resulting in development of cytokine storm syndromes and pulmonary tissue damage. Cytokine storm syndromes are also referred to as hypercytokinaemia, which are group of disorders and characterised by the uncontrolled production of pro-inflammatory cytokines leading towards acute respiratory distress syndrome (ARDS) and multiple organ failure such as lungs, heart, intestine and blood vessels (Wang and Ma, 2008; Channappanavar and Perlman, 2017; Villar et al., 2019; Li et al., 2020a). After infection, there is an incubation period of 2-14 days until the onset of symptoms and the common symptoms are fever, dry cough and tiredness. The less commonly occurring symptoms are headache, loss of taste and smell, sore throat, diarrhea, aches and pain, etc. Among serious symptoms, there is difficulty in breathing with chest pain or pressure followed by loss of speech and movement. Out of total, about $80 \%$ of cases are with mild symptoms or may be asymptomatic while rest of $15 \%$ and $5 \%$ are severe who need oxygen and ventilation, respectively (Lauer et al., 2020; Seyed et al., 2020; Singal, 2020; Saleem et al., 2021).

\section{Functional foods}

The term 'functional food' was firstly used in Japan and further it was reported that food can be used for other functions rather than nutrient supply, gastronomic pleasure and energy (Lo'pez-Varela et al., 2002). The Functional Food Center (FFC) defines "functional food" as natural or processed foods that contains known or unknown biologically-active compounds; the foods, in defined, effective, and non-toxic amounts, provide a clinically proven and documented health benefit for the prevention, management, or treatment of chronic disease (Martirosyan and Singh, 2015). In Japan, functional foods have been legislated in the FOSHU (Foods of Specified Health Use) legislation and the food products which meeting specific requirements are given FOSHU stamp. In Europe, experts decided in the FUFOSE (Functional Food Science in Europe) project to adopt the term 'functional food' with a consensus definition. The criteria for defining functional foods under FOSHU (Foods of Specified Health Use) and FUFOSE (Functional Food Science in Europe) in Japan and Europe has been explained in Figure 1 (López-Varela et al., 2002).

The potential immunomodulatory and antiviral properties can be gained from various functional food plants, such as ginger, garlic, turmeric, black pepper, liquorice, pomegranate and elderberry (Yang et al., 2020). The various bioactive compounds like polyphenols and carotenoids have antiviral efficacy. For example, polyphenols has been reported to influence the regulation of immune cells, the synthesis of pro-inflammatory cytokines and the suppression of pro-inflammatory gene expression (Yahfoufi et al., 2018). The functional foods and components contain biologically-active compounds which are having immune-boosting properties. These natural compounds are not involved in the direct inhibition response against corona virus, but strengthen the immunity which acts as preventive defence against COVID-19. The prebiotics, probiotics, and ayurvedic products reduce the stress level of the body, strengthen the immune response in our body and keep the gut healthy by maintaining microflora and bacterial colonies (López-Varela et al., 2002; Singh et al., 2020).

\section{Functional food components and COVID-19}

The various viral infections in human are characterized by a compromised immune function and deficient micronutrient stores, particularly vitamins and trace elements (Calder et al., 2020). The efficient functioning of the immune system can be maintained by consuming various nutraceuticals within a variety of functional foods and supplementation of such functional foods (Figure 2) with adequate dietary intake boosts up the immune system and provides an important antiviral prevention of COVID-19 (Alkhatib, 2020; Gombart et al., 2020; Grant et al., 2020). The majority of functional food which boosts up antiviral immune defence includes variety of plant, animal, and fungi species such as teas, roots, mushrooms, fermented plants/leaves, olive-based products, oily fish, seeds, fruits, vegetables, popular beverages and protein-rich foods like chicken extract and soybean peptides. Fruits and vegetables plays an important role in human nutrition and health because of the abundance of bioactive or functional compounds like polyphenolics, vitaminsC, folic acid, dietary fibres and minerals (Sharma et al., 2019; Sharma et al., 2020). The bioactives from fruits and their by-products can be used for the formulation of new products with positive pharmacological effects which can maintain or improve health (Hamid et al., 2020). These foods have immunoprotective properties due to the antioxidation and anti-inflammation compounds like naturally occurring vitamins and minerals (e.g., vitamins like A, C, D, $\mathrm{B}_{6}, \mathrm{~B}_{12}$, $\mathrm{E}$ and minerals like zinc, copper, iron, and selenium), and other phenolic compounds (López-Varela, 2002; Alkhatib and Tuomilehto, 2019). The potential antiviral benefits or role in COVID-19 of different compounds present in functional foods have been further discussed in detail and some important aspects have been mentioned in Tables 1-3.

\subsection{Vitamins}

Among all vitamins, vitamin $\mathrm{A}, \mathrm{B}, \mathrm{C}, \mathrm{D}$, and $\mathrm{E}$ have been reported to be most effective on immune system, and play an important role in prevention of several viral infections including COVID-19. On the basis of enhancement of immune system, group B vitamins $(42.18 \%)$ are most studied followed by vitamin A, D, and E (26.66\%, 22.22\% and $13.33 \%$ ). With respect to prevention/treatment of COVID-19 infection, most of the studies had been focused on vitamin $\mathrm{D}(66.66 \%)$ followed by vitamin C (50\%), E (33.33\%) and A (16.66\%), respectively (Dehghani-Samani et al., 2020). These different vitamins act as immune promoting functional component in various functional foods and sufficient vitamin intake can be recommended to prevent viral infections like COVID-19 infection.

\subsubsection{Vitamin A}

Vitamin A is having anti-inflammation properties and it plays a crucial role in enhancing immune function which further plays regulatory roles in cellular and humoral immune responses or processes. It plays various important functions in human body like maintaining vision, promoting growth and development, and protecting epithelium and mucus integrity in the body (Huang et al., 2018; Thakur et al., 
2019). Villamor and Fawzi (2005) have reported that vitamin A supplementation to preschool children can decrease the risks of mortality and morbidity from some diseases like diarrhea, measles, human immunodeficiency virus (HIV) infection, and malaria. 9-cisretinoic acid which is a metabolite of vitamin $\mathrm{A}$ is required for $\mathrm{CD} 8^{+}$ T normal functioning of B lymphocytes including antibody generation and also for lymphocyte survival and proliferation (Ross 1996 and Calder, 2020).

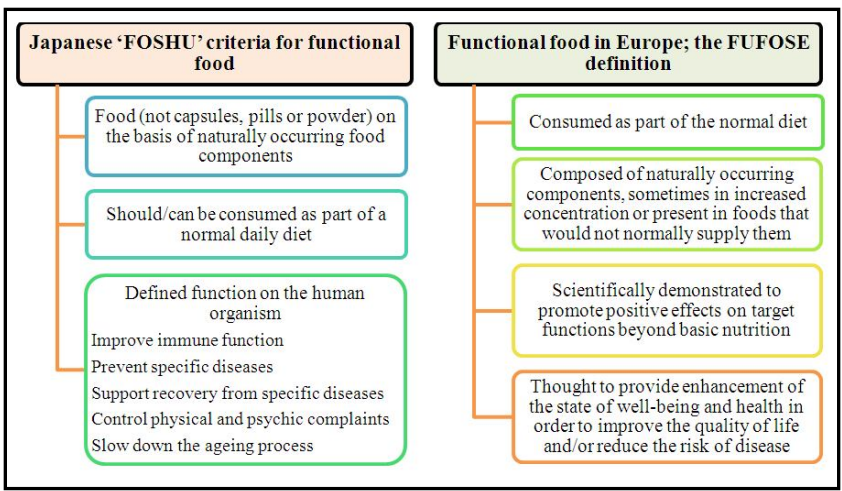

Figure 1: Criteria for defining functional foods under FOSHU (Foods of Specified Health Use) and FUFOSE (Functional Food Science in Europe) in Japan and Europe (Lo'pez-Varela et al., 2002).

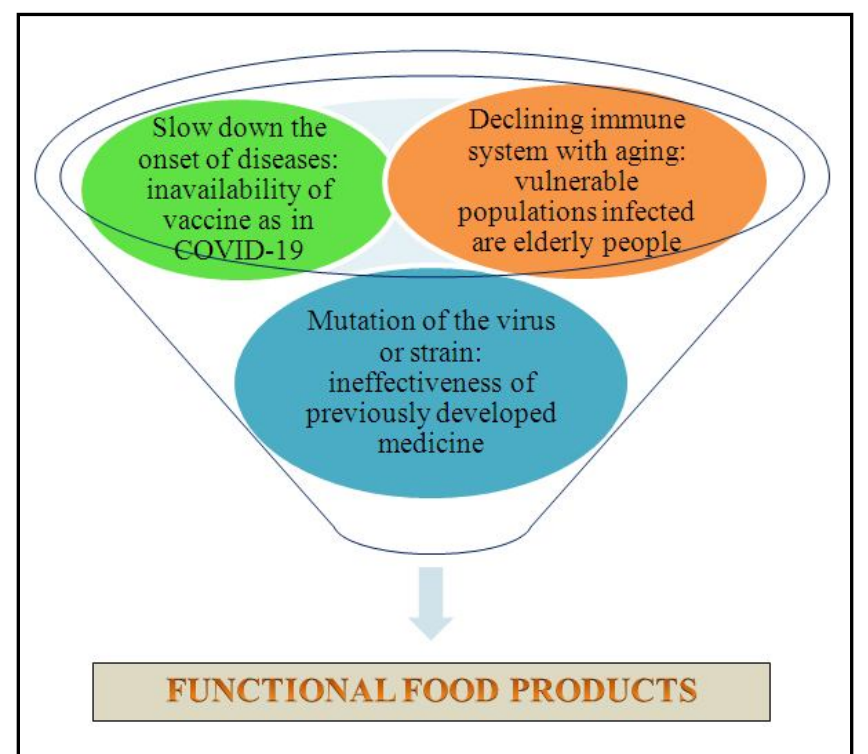

Figure 2: Development of specific functional foods products for viral diseases (Martirosyan, 2020).

\subsubsection{Vitamin B}

Vitamin B has important role in assisting in proper activation of innate and adaptive immune responses and decreasing the proinflammatory cytokine levels, improves respiratory function, maintains endothelial integrity and prevents hypercoagulability which in turn can reduce the length of stay in hospital during viral infection. On the basis of above benefits, vitamin B status should be assessed in COVID-19 patients and could be used as a nonpharmaceutical adjunct to current treatments (Michele et al., 2020; Zhang and Liu, 2020; Shakoor et al., 2021). Vitamin $\mathrm{B}_{1}$ has been reported to have antioxidative effect, suppression of oxidative stress and role in NF- $\mathrm{kB}$ regulation in the immune system (Mikkelsen et al., 2017). On the basis of role of Vitamin $B_{1}$, Dehghani-Samani et al. (2020) suggested the need of further studies on its effect in COVID19 infected patients. In SARS-CoV-2 virus infection, antibodies and T-cells are helpful to eliminate the virus and thiamine deficiency can potentially result in inadequate antibody responses with more severe symptoms. So, by maintaining adequate levels of thiamine, it will help in assisting in the proper immune responses during SARS-CoV2 infection (Shakoor et al., 2021). The researchers further reported that riboflavin together with UV light causes irreversible damage to nucleic acids rendering microbial pathogens and could alleviate some of the risk of transfusion transmission of COVID-19 as well as reducing other pathogens in blood products for critically ill COVID19 patients.

Vitamin $\mathrm{B}_{6}$ is an essential factor for maintenance of lymphoid tissues and their immunological functions like different kind of cell-mediated reactions and antibodies related reactions (Chandra and Sudhakaran, 1990). Pyridoxal 52-phosphate which is active form of vitamin $B_{6}$ can dampen the cytokine storm and inflammation caused due to excessive $\mathrm{T}$ cell response and secretion of pro-inflammatory cytokines during COVID-19 infection (Shakoor et al., 2021). Vitamin $\mathrm{B}_{9}$ (folate) plays a key role in the nucleic acid synthesis and normal cellular function with potential pathologic impact and during its deficiency supplementation with folate should be encouraged in COVID-19 hospitalized patients (Meisel et al., 2021). Sheybani et al. (2020) reported that folic acid could be used to inhibit the furin enzyme which further affect the structure of the protein and interfere with its proteolytic capability. The researchers further suggested the use of folic acid as a safe drug and in the early stages of the COVID-19 disease it could be useful in the prevention or management of associated respiratory diseases. Vitamin $\mathrm{B}_{12}$ and its active forms hydroxo-, adenosyl- and methylcobalamin has various important functions in human which includes red blood cell synthesis, nervous system health, myelin synthesis, cellular growth and the rapid synthesis of DNA (Mikkelsen et al., 2017; Shakoor et al., 2021). Santos (2020) has reported vitamin $B_{12}$ therapy can reduce the oxidative stress along with improving circulation and further COVID19-related organ damage and symptoms can be reduced with the help of methylcobalamin supplements.

\subsubsection{Vitamin $C$}

Vitamin $\mathrm{C}$ is a potential therapeutic option in management of COVID19 due to its various pharmacological characteristics; antiviral, antioxidant, anti-inflammatory and immunomodulatory effects; leucocyte migration to sites of infection; phagocytosis and bacterial killing; natural killer cell activity and $\mathrm{T}$ lymphocyte function (especially of $\mathrm{CD}^{8+}$ cytotoxic $\mathrm{T}$ lymphocytes) and antibody production (Abobaker et al., 2020; Calder, 2020). In China and United States, the use of high dose of intravenous vitamin $\mathrm{C}$ has shown promising results in management of COVID-19 during the treatment of infected patients with no reported adverse reactions with the short-term use of its high doses. The possible beneficial effects of vitamin $\mathrm{C}$ in management of COVID-19 are indirect antiviral effects by improving host's innate immunological responses, immunomodulatory effects by improving $\mathrm{T}$ cell functions with increased production of immunoglobulins, antiinflammatory effect by decreasing the risk of cytokine storm, antioxidant effects by decreasing oxidative stress induced lung 
inflammation with restoring endothelial function and decreases the duration of mechanical ventilation or vasopressor requirements in critically ill patients (Abobaker et al., 2020). Carr and Rowe (2020) reported that vitamin $\mathrm{C}$ administration will improve outcomes in COVID-19 on the basis of clinical trials of patients with pneumonia and sepsis, and preliminary observational and interventional studies.

Table 1: Antiviral functional food sources of immune promoting vitamins: functions and effects on respiratory system

\begin{tabular}{|c|c|c|c|c|c|}
\hline Vitamin & $\begin{array}{l}\text { Antiviral functional } \\
\text { food sources }\end{array}$ & $\begin{array}{l}\text { Key mechanism } \\
\text { of action }\end{array}$ & $\begin{array}{l}\text { Recommendations } \\
\text { and deficiency }\end{array}$ & $\begin{array}{l}\text { RDA* (for Indians } \\
\text { 2020) }\end{array}$ & References \\
\hline Vitamin A & $\begin{array}{l}\text { Orange, carrots, sweet } \\
\text { potatoes, broccoli, } \\
\text { pumpkin, squash, kale, } \\
\text { spinach, milk, cheese, } \\
\text { oily fish, liver, eggs, } \\
\text { fortified cereals, } \\
\text { apricots, } \\
\text { papaya, peaches, } \\
\text { mango, tomato juice, } \\
\text { cantaloupe melon. }\end{array}$ & $\begin{array}{l}\text { - Maintains lymphocyte } \\
\text { pool and T lymphocyte } \\
\text { synthesis, results in } \\
\text { resistance to infection. } \\
\text { - Epithelial cell differen- } \\
\text { tiation and immune com- } \\
\text { petence are maintained } \\
\text { - Improves functions of } \\
\text { neutrophils, macrophages } \\
\text { and natural killer cells. } \\
\text { - Key role in the division } \\
\text { of T lymphocytes } \\
\text { - Prevention and treatment } \\
\text { of respiratory tract } \\
\text { infection }\end{array}$ & $\begin{array}{l}\text { Recommended as part } \\
\text { of a balanced diet. } \\
\text { Deficiency leads to } \\
\text { night blindness. }\end{array}$ & $\begin{array}{l}1000 \mu \mathrm{g} / \mathrm{day} \text { for men } \\
\text { and } 850 \mu \mathrm{g} / \mathrm{day} \text { for } \\
\text { women }\end{array}$ & $\begin{array}{l}\text { Mahalanabis et al. } \\
2004 \\
\text { Tanumihardjo et al., } \\
2016\end{array}$ \\
\hline Vitamin $B_{6}$ & $\begin{array}{l}\text { Garlic, cloves, walnut, } \\
\text { sunflower seeds, saff- } \\
\text { lower, pistachio nut, } \\
\text { poultry chicken, liver, } \\
\text { sugarcane, oyster } \\
\text { mushroom, fish, eggs, } \\
\text { whole grain cereals, } \\
\text { green leafy vegetables, } \\
\text { fortified cereals, fruits, } \\
\text { tofu, soya beans }\end{array}$ & $\begin{array}{l}\text { - Aids in the control of the } \\
\text { inflammatory response. } \\
\text { - Operation of NK cells. } \\
\text { - Participates in the syn- } \\
\text { thesis of amino acids, } \\
\text { cytokines, and antibodies. } \\
\text { - Proliferation, differenti- } \\
\text { ation and maturation of } \\
\text { lymphocytes. }\end{array}$ & $\begin{array}{l}\text { Should be part of a } \\
\text { balanced diet. } \\
\text { Periphera neuritis, } \\
\text { eczema, angular } \\
\text { stomatitis, } \\
\text { hyperirritability, } \\
\text { convulsive seizures, } \\
\text { and pathological } \\
\text { electroencephalo } \\
\text { grams. }\end{array}$ & $\begin{array}{l}1.9-3.1 \mathrm{mg} / \text { day for } \\
\mathrm{men} \text { and } 1.9-2.4 \\
\mathrm{mg} / \text { day for women }\end{array}$ & $\begin{array}{l}\text { Meydani et al., } \\
1991 \\
\text { Saeed } \text { et al., } 2016\end{array}$ \\
\hline $\begin{array}{l}\text { Vitamin } \\
\mathrm{B}_{12}\end{array}$ & $\begin{array}{l}\text { Meat, fish, shellfish, } \\
\text { eggs, milk, cheese, } \\
\text { yeast extract, fortified } \\
\text { breakfast cereals. }\end{array}$ & $\begin{array}{l}\text { - Acts as immunomodulator } \\
\text { - Acts on the NK cells } \\
\text { functions } \\
\text { - Assists in T lymphocytes } \\
\text { production, } \\
\text { - Contribution in antibodies } \\
\text { production and its } \\
\text { metabolism }\end{array}$ & $\begin{array}{l}\text { Recommended as a } \\
\text { part of a balanced } \\
\text { diet. Deficiency leads } \\
\text { pernicious anemia. }\end{array}$ & $\begin{array}{l}2.5 \mu \mathrm{g} / \text { day for men } \\
\text { and women }\end{array}$ & $\begin{array}{l}\text { Saeed } \text { et al., } 2016 \\
\text { Maggini } \text { et al., } \\
2018\end{array}$ \\
\hline Vitamin $B_{9}$ & $\begin{array}{l}\text { Green leafy vegetables } \\
\text { like spinach, cabbage, } \\
\text { kale, broccoli, brussels } \\
\text { sprouts, peas, fortified } \\
\text { cereals, chick peas }\end{array}$ & $\begin{array}{l}\text { - Adds to the conservation } \\
\text { of innate immunity } \\
\text { - Contribute to the antigen- } \\
\text { specific antibody response } \\
\text { - Expansion of T cells }\end{array}$ & $\begin{array}{l}\text { Dietary intake is } \\
\text { highly recommended. } \\
\text { Deficiencies associated } \\
\text { with elevated blood } \\
\text { homocysteine levels. }\end{array}$ & $\begin{array}{l}300 \mu \mathrm{g} / \mathrm{day} \text { for men } \\
\text { and } 220 \mu \mathrm{g} / \text { day for } \\
\text { women }\end{array}$ & $\begin{array}{l}\text { Budi } \text { et al., } 2015 \\
\text { Saeed } \text { et al., } 2016\end{array}$ \\
\hline Vitamin C & $\begin{array}{l}\text { Aonla, barbados cherry, } \\
\text { oranges, lemon, red and } \\
\text { green peppers, straw- } \\
\text { berries, blackcurrants, } \\
\text { kiwi, broccoli, brussels } \\
\text { sprouts, and potatoes }\end{array}$ & $\begin{array}{l}\text { Immunosenescence and } \\
\text { positive regulation of the } \\
\text { ageing phase, } \\
\text { - Modulation of the low- } \\
\text { grade inflammatory path } \\
\text { way in a positive way } \\
\text { - Improves phagocyte chem- } \\
\text { otaxis and motility. } \\
\text { - Improvement of antibody } \\
\text { amounts, specificity and } \\
\text { replication. } \\
\text { - Modulates the synthesis of } \\
\text { inflammatory cytokines. } \\
\text { - Function in respiratory } \\
\text { infection prevention and } \\
\text { management }\end{array}$ & $\begin{array}{l}\text { Dietary intake is } \\
\text { preferred. } \\
\text { Supplementation is } \\
\text { required during low } \\
\text { dietary intake. } \\
\text { Deficiency leads to } \\
\text { scurvy. }\end{array}$ & $\begin{array}{l}80 \mathrm{mg} / \mathrm{day} \text { for men } \\
\text { and } 65 \mathrm{mg} / \mathrm{day} \text { for } \\
\text { women }\end{array}$ & $\begin{array}{l}\text { Monacelli et al., } \\
2017 \text {; } \\
\text { Carr and Maggini, } \\
2017 \\
\text { Mousavi et al., } 2019\end{array}$ \\
\hline
\end{tabular}




\begin{tabular}{|c|c|c|c|c|c|}
\hline & & $\begin{array}{l}\text { Reduces the number of } \\
\text { pathogens. } \\
\text { - Reduces the pathogenic pot- } \\
\text { ential of viruses, bacteria } \\
\text { and other pathogens (fungi } \\
\text { and parasites) }\end{array}$ & & & \\
\hline Vitamin D & $\begin{array}{l}\text { Oily fish, liver, eggs, } \\
\text { fortified foods, spreads } \\
\text { and some breakfast } \\
\text { cereals }\end{array}$ & $\begin{array}{l}\text { - Viral replication is reduced. } \\
\text { - In bronchial epithelial cells } \\
\text { it stimulates the innate } \\
\text { immune response. } \\
\text { - Stimulates the division of } \\
\text { monocytes into macro- } \\
\text { phages. } \\
\text { - Antibacterial protein } \\
\text { synthesis is stimulated. } \\
\text { - Stimulates the mechanisms } \\
\text { involved in pathogen } \\
\text { elimination. } \\
\text { - Supplementation appears } \\
\text { to guard against respiratory } \\
\text { tract infections (mostly } \\
\text { in people with } \\
\text { hypovitaminosis). }\end{array}$ & $\begin{array}{l}\text { Supplementation is } \\
\text { required during low } \\
\text { dietary intake } \\
\text { Deficiency leads to } \\
\text { abnormal calcium } \\
\text { homeostasis resulting } \\
\text { rickets in children or } \\
\text { osteomalacia in adults }\end{array}$ & $\begin{array}{l}600 \mathrm{IU} / \text { day for men } \\
\text { and women }\end{array}$ & Medrano et al., 2018 \\
\hline Vitamin E & $\begin{array}{l}\text { Nuts and seeds, } \\
\text { vegetable oils, wheat } \\
\text { germ }\end{array}$ & $\begin{array}{l}\text { - Membrane anti - oxidant } \\
\text { protection } \\
\text { - Enhances lymphocyte } \\
\text { proliferation } \\
\text { - Increases NK cell activity } \\
\text { - Have anti-inflammatory } \\
\text { properties (against colds } \\
\text { and pneumonia) }\end{array}$ & $\begin{array}{l}\text { Dietary intake is } \\
\text { recommended. } \\
\text { Supplementation is } \\
\text { required during low } \\
\text { dietary intake. }\end{array}$ & $8-10 \mathrm{mg}$ tocopherol/d & $\begin{array}{l}\text { Hemila, } 2016 \\
\text { Lee and Haan, } 2018\end{array}$ \\
\hline
\end{tabular}

*RDA range is only for sedentary, moderate and heavy workers as per recommendations of NIN (National institute of nutrition) HyderabadIndia.

\subsubsection{Vitamin D}

The active form of vitamin $\mathrm{D}$ is 1,25 -dihydroxy Vit $\mathrm{D}_{3}\left(1,25(\mathrm{OH})_{2} \mathrm{D}_{3}\right)$ has roles in bone formation by regulating the calcium and phosphorus metabolisms. It also leads to immunomodulation of different immune cells via affecting the monocytes, macrophages, dendritic cells, Tcells and B-cells, with important effects on innate and adaptive immune responses (Baeke et al., 2010; Dehghani-Samani et al., 2020). Ali (2020) reported that vitamin D supplementation is safe and effective against acute respiratory tract infections and the people having higher risk of vitamin D deficiency during COVID-19 should take vitamin D supplements to maintain the circulating 25(OH)D in the optimal levels $(75-125 \mathrm{nmol} / \mathrm{l})$. The vitamin $\mathrm{D}$ serum concentrations should be inbetween 40 and $60 \mathrm{ng} / \mathrm{ml}(100-150 \mathrm{nmol} /$ 1) during all the year and can reduce the risk of respiratory tract infections including COVID-19 infection (Cutolo et al., 2020). The various mechanisms involved with the adequate vitamin $\mathrm{D}$ availability and reduction in the risk of viral and COVID-19 infections has been mentioned in Figure 3.

\subsubsection{Vitamin E}

Vitamin $\mathrm{E}$ is a potent antioxidant and important nutrient for maintaining the immune system, especially in the elderly people (Moriguchi and Muraga, 2000). It plays a role in the differentiation of immature $\mathrm{T}$ cells in the thymus with ability to modulate host immune functions and decrease in cellular immunity with ageing or degenerative diseases can be improved by the intake of a high vitamin E rich diet (López-Varela et al., 2002). Vitamin E acts as an essential factor in enhancing the production of natural killer cells and interleukins with significant contribution in the proliferation of lymphocytes and elicits a robust immune reaction against pathogens (Gombart et al., 2020; Junaid et al., 2020). The above all findings support the potential therapeutic use of vitamin E against COVID-19.

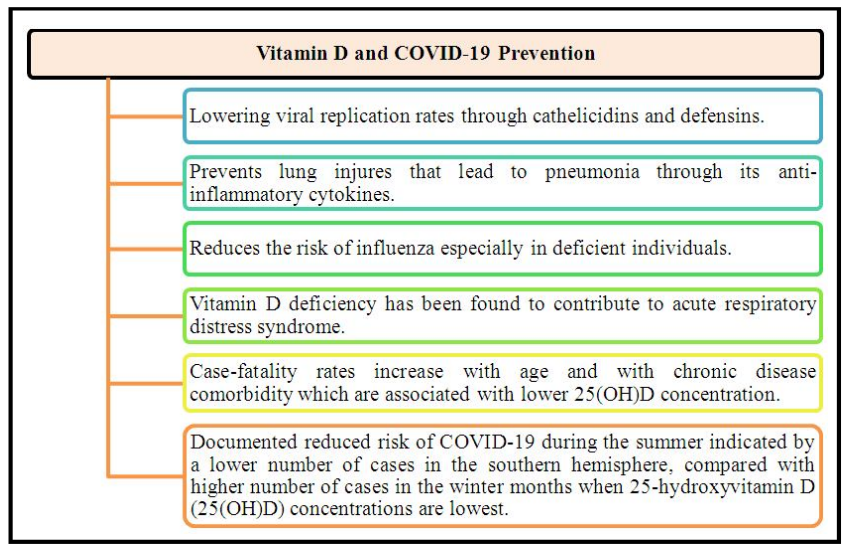

Figure 3: Mechanisms involved with the adequate vitamin D availability and reduction in the risk of viral and COVID-19 infections (Martineau et al., 2019 and Alkhatib, 2020).

\subsection{Minerals}

A number of trace elements iron, zinc, selenium and copper have been shown to be important for adequate functioning of the immune 
system and play a crucial role in biological processes, such as oxygen transport, cell growth and differentiation, and protection against oxidative stress. While their deficiencies can affect the antibody responses, cell-mediated immunity, and natural killer (NK) cell activity (Thakur et al., 2019).

\subsubsection{Zinc}

Zinc is associated with immunological properties and is very essential for highly proliferating cells, normal development and functioning of cell-mediating innate immunity and acts as an essential cofactor for thymulin which modulates cytokine release and induces proliferation (Maggini et al., 2007; Prasad, 2009; Alpert, 2017). Due to its immune response and antiviral action, zinc may be considered as adjunct therapeutic agent for COVID-19 patients and zinc supple-mentation can be used to mitigate the severity of disease in this population (Bhatt et al., 2020). Finzi (2020) reported that high dose of zinc lozenges (zinc citrate/gluconate $23 \mathrm{mg}$, and zinc acetate $15 \mathrm{mg}$ ) given to COVID-19 patients resulted in improvement of oxygenation with zinc gluconate along with alleviation of symptoms.

\subsubsection{Selenium}

Selenium is an essential micronutrient which helps in up-regulation of expression of the $\alpha$ and $\beta$ subunits of the IL-2 receptor along with boosting up the immune system by increasing the cytotoxicity of killer cells, numbers of lymphocytes and promotes antibody production by B lymphocytes (McKenzie et al., 2002; Thakur et $a l ., 2019)$. Selenium is required for the effective and efficient functioning of the immune system. It enhances the function of cytotoxic effector cells and have an important role in maintaining $\mathrm{T}$ cell maturation and functions, as well as for T cell-dependent antibody production (Bae and Kim, 2020). Kieliszeka and Lipinskib (2020) reported that selenium can potentially be used in the recent battle against coronavirus epidemic. Selenium deficiency has been found associated with mortality in COVID-19 and a sufficient selenium level is important for recovery from the disease (Moghaddam et al., 2020; Zhang et al., 2020)

\subsubsection{Iron}

Iron is a part of the haem protein present in haemoglobin and in human body it is responsible for supplying oxygen to tissues. As a part of cytochromes it plays an important role in the transportation of the mitochondrial electron and it effects in broad spectrum leading to impairment of the respiratory burst, killing of bacteria, proliferation of T-cells and development of cytokines (Kumar and Choudhry, 2010; Dhok, 2020). Iron chelation therapy could be considered to improve survival and overall long-term outcome in appropriate setting of critically ill patients with COVID-19 due to the beneficial effects of iron chelation therapy on the inflammatory status as well as on the fibrogenesis occurring in the lungs (Perricone et al., 2020). Ferrous/ferric oxide which is an inert material is used for preparing nano-particles in nanotechnology and these nanomaterials are used widely in the global fight against COVID-19 pandemic by preparing personal protection equipment's (PPE's) diagnostic tests and manufacture effective vaccines or antiviral drugs (Bhatt et al., 2020; Liu et al., 2020)

\subsubsection{Copper}

Copper is an essential micronutrient which is involved in the functions of critical immune cells like $\mathrm{T}$ helper cells, B cells, neutrophils, natural killer (NK) cells and macrophages which are involved in the killing of infectious microbes including SARS-CoV-2, cell-mediated immunity and the production of pathogen specific antibodies (Raha et al., 2020). Studies conducted by Andreou et al. (2020) supports the combination of copper, $\mathrm{N}$-acetylcysteine (NAC), colchicine and nitric oxide (NO) with antiviral agents, remdesivir or EIDD-2801, as a treatment for patients infected with SARS-CoV-2. Copper destroys the replication and propagation abilities of SARS-CoV, influenza and other respiratory viruses which help to reduce the transmission of several infectious diseases by limiting nosocomial infectious transmission. Copper oxide or nano-compounds may be used for preparing nano-particles in nanotechnology which are further used to manufacture filters, face masks, clothing, etc. (Cortes and Zuñiga, 2020). Copper signalling, its vulnerability, method of assessment and interpretation, administration rout and dosage opens up new perspectives regarding therapeutic copper administration against critically ill COVID-19 patients (Fooladi et al., 2020).

\subsection{Phenolic compounds}

Phenolic compounds are a class of the most widely distributed secondary metabolites in plants and are commonly found in various products of natural origin like fruits, vegetables, food grains, seeds, flowers, tea, wine, honey and forages. Phenolic compounds have been recognized as dietary factors responsible for potential effects on human health and they have been widely used to increase functionality of some foods (Quirós-Sauceda et al., 2014). The various phenolic compounds have unique antioxidant activity which contributes towards its medicinal value and human health benefits (Kashyap et al., 2017 and Thakur et al., 2020). Traditionally, the polyphenols rich plant derived folk medicines are used to cure disorders of the blood stream including blood pressure, antiviral effects, stomach disorders, antiseptic action, dressing of burns or inflammation and inhibition of direct acting mutagens. These are the major class of compounds that show great activity against various viruses such as retrovirus, hepadnavirus, hespesvirus, HIV virus, influenza virus, herpes simplex virus, dengue virus, polio virus, etc. (Kamboj et al., 2012; Wan-Fei et al., 2017).

Due to the tremendous pharmacokinetic properties, flavonoid and phenolic compounds are most promising active compounds among the chemically diverse natural therapeutic agents used for against SARS-CoV-2 (Sayed et al., 2020; Islam et al., 2020). Rathinavel et al. (2020) reported that phenolic compounds such as quercetin, rosmarinic acid and hesperetin show good binding affinity with SARSCoV-2 viral protein targets with an excellent physicochemical or pharmacokinetic property and these phenolic drugs may best suit to treat COVID-19. These researchers further suggested use of these phenolic compounds for COVID-19 treatment practices as they can act as nutritional supplements and promote the immune system of the body to combat COVID-19 infection. The polyphenolic drugs can act as antiviral in nature as they can inhibit coronavirus enzymes, which are required for virus replication and infection. For the inhibition of viral proteases, the various natural substances like betulinic acid, indigo, luteolin, quinomethyl triterpenoids, quercitin and gallates can act as a potential key to designing antiviral therapies. These polyphenols might provide a starting point for the research on the use of plant extracts for the development of new anti-Covid19 formulations and these formulations containing phytochemicals have high safety for patients with no side effects (Chojnacka et al., 2020). Khalil and Tazeddinova (2020) reported that polyphenols can be considered as a potential and valuable source for designing new drugs that could be used for the treatment of COVID-19 infection. 
Table 2: Antiviral functional food sources of immune promoting minerals: functions and effects on respiratory system

\begin{tabular}{|c|c|c|c|c|c|}
\hline Mineral & $\begin{array}{l}\text { Antiviral functional } \\
\text { food sources }\end{array}$ & $\begin{array}{l}\text { Key mechanism } \\
\text { of action }\end{array}$ & $\begin{array}{l}\text { Recommendations } \\
\text { and deficiency }\end{array}$ & $\begin{array}{l}\text { RDA* (for } \\
\text { Indians 2020) }\end{array}$ & References \\
\hline Zinc & $\begin{array}{l}\text { Shellfish, meat, cheese, } \\
\text { grains, seeds, cereals, } \\
\text { seeded or wholegrain } \\
\text { breads }\end{array}$ & $\begin{array}{l}\text { - Zinc deficiency: reduction } \\
\text { in innate immunity. } \\
\text { - Role in immune cell matu- } \\
\text { ration and differentiation. } \\
\text { - Increases the number and } \\
\text { function of natural killer } \\
\text { cells } \\
\text { - Inflammatory cytokine } \\
\text { regulation } \\
\text { - Involvement in anti- } \\
\text { inflammatory pathways }\end{array}$ & $\begin{array}{l}\text { Supplementation is } \\
\text { required during low } \\
\text { dietary intake espe- } \\
\text { cially in older adults. } \\
\text { Deficiency leads to } \\
\text { depressed immunity, } \\
\text { growth failure, } \\
\text { diarrhoea, anorexia, } \\
\text { altered skeletal } \\
\text { function and repro- } \\
\text { ductive failure. }\end{array}$ & $\begin{array}{l}17 \mathrm{mg} / \text { day for } \\
\mathrm{men} \text { and } 13.2 \\
\mathrm{mg} / \text { day for } \\
\text { women }\end{array}$ & $\begin{array}{l}\text { Bonaventura et al., } \\
2015 \\
\text { Maares and Haase, } \\
2016\end{array}$ \\
\hline Selenium & $\begin{array}{l}\text { Fish, shellfish, eggs, } \\
\text { meat, nuts like brazil } \\
\text { nuts }\end{array}$ & $\begin{array}{l}\text { - Necessary for the activity } \\
\text { of selenoproteins, which is } \\
\text { vital for the host's antio- } \\
\text { xidant protection }\end{array}$ & $\begin{array}{l}\text { Supplementation is } \\
\text { recommended when } \\
\text { intake is low. } \\
\text { Its deficiency has } \\
\text { been linked to } 2 \\
\text { endemic diseases in } \\
\text { children and } \\
\text { adolescents. }\end{array}$ & $\begin{array}{l}40 \mu \mathrm{g} / \mathrm{day} \text { for } \\
\text { men and women }\end{array}$ & $\begin{array}{l}\text { Zhang and Liu, } \\
2020\end{array}$ \\
\hline Iron & $\begin{array}{l}\text { Meat, liver, beans, nuts, } \\
\text { dried fruit, fortified } \\
\text { cereals, wholegrains, } \\
\text { dark green leafy } \\
\text { vegetables (spinach, } \\
\text { kale) }\end{array}$ & $\begin{array}{l}\text { - Iron is needed for the } \\
\text { development and action } \\
\text { of inflammatory } \\
\text { cytokines including IFN-, } \\
\text { TNF-, IL-2, and IL-10. } \\
\text { - Generation of reactive } \\
\text { oxygen species (ROS) that } \\
\text { destroys the pathogen that } \\
\text { infects immune system. } \\
\text { - Helps to control the pro- } \\
\text { portion of T helper and } \\
\text { cytotoxic T cells. }\end{array}$ & $\begin{array}{l}\text { Dietary intake is } \\
\text { recommended. } \\
\text { Supplementation is } \\
\text { required during low } \\
\text { dietary intake. } \\
\text { Major deficiency- } \\
\text { anemia }\end{array}$ & $\begin{array}{l}19 \mathrm{mg} / \text { day for } \\
\text { men and } 29 \\
\mathrm{mg} / \text { day for } \\
\text { women }\end{array}$ & $\begin{array}{l}\text { Budi et al., 2015; } \\
\text { Center, } 2016 \\
\text { Wu et al., } 2018\end{array}$ \\
\hline Copper & $\begin{array}{l}\text { Nuts,shellfish, liver, } \\
\text { some vegetables }\end{array}$ & $\begin{array}{l}\text { - Linked with superoxide } \\
\text { dismutase (SOD) enzyme, } \\
\text { which is involved in the } \\
\text { protection against reactive } \\
\text { oxygen species (ROS). } \\
\text { - Classified as a free radical } \\
\text { scavenger and maintains } \\
\text { intracellular antioxidant } \\
\text { balance. } \\
\text { - In animal studies, it is } \\
\text { involved in T cell diffe- } \\
\text { rentiation and prolifera- } \\
\text { tion, antibody formation, } \\
\text { and cellular immunity. }\end{array}$ & $\begin{array}{l}\text { Dietary intake is } \\
\text { highly recommended. } \\
\text { Anemia, vascular } \\
\text { complications, } \\
\text { osteoporosis, } \\
\text { and neurological } \\
\text { symptoms are also } \\
\text { signs of copper } \\
\text { deficiency. }\end{array}$ & $\begin{array}{l}2 \mathrm{mg} / \mathrm{day} \text { for } \\
\text { men and women }\end{array}$ & $\begin{array}{l}\text { Maggini et al., } \\
2007 ; \\
\text { Saeed et al., 2016; } \\
\text { Alpert, } 2017 \\
\text { Maggini et al., } \\
2018\end{array}$ \\
\hline
\end{tabular}


Table 3 : Antiviral functional food sources of immune promoting phenolic compounds and their mode of action

\begin{tabular}{|c|c|c|c|}
\hline $\begin{array}{l}\text { Bioactive } \\
\text { components }\end{array}$ & Bioactive components sources & Key mechanism of action & References \\
\hline Polyphenols & $\begin{array}{l}\text { Apple, pomegranate, aonla, } \\
\text { apricots, papaya, peaches, mango, } \\
\text { pumpkin, spinach, broccoli, orange, } \\
\text { tomato, berries, jamun }\end{array}$ & $\begin{array}{l}\text { Prevent and counteract inflammation by } \\
\text { mitigating inflammatory response in } \\
\text { adipocytes, macrophages, and additional } \\
\text { immune cells }\end{array}$ & $\begin{array}{l}\text { Godfrey et al., 2012; } \\
\text { Hamid et al., 2017; } \\
\text { Lin et al., 2017; } \\
\text { Kaihatsu et al., } 2018\end{array}$ \\
\hline Curcumin & Turmeric & $\begin{array}{l}\text { Immunomodulator, modulate dendritic cells } \\
\text { and anti-inflammatory }\end{array}$ & $\begin{array}{l}\text { Thakur et al 2018; } \\
\text { Gianchecchi and Fierabracci, } \\
\text { 2020; }\end{array}$ \\
\hline $\begin{array}{l}\text { Catechins(-)- } \\
\text { epigallocate- } \\
\text { chin-3-gallate } \\
\text { (EGCG) }\end{array}$ & $\begin{array}{l}\text { Green tea, apples, blueberries, } \\
\text { gooseberries, grape seeds, kiwi, } \\
\text { strawberries, red wine }\end{array}$ & $\begin{array}{l}\text { Enveloped DNA, (+)-RNA and (-)-RNA viruses } \\
\text { may be inhibited by natural catechins, but by } \\
\text { inhibiting reverse transcriptase in vitro and } \\
\text { in vivo, EGCG showed a high capacity to } \\
\text { prevent the initial stages of infections, } \\
\text { including binding, postadsorption entrance, } \\
\text { and genomic multiplication, by interfering } \\
\text { with viral protein complexes as well as cellular } \\
\text { processes }\end{array}$ & $\begin{array}{l}\text { Levy et al., } 2020 ; \\
\text { Li } \text { et al., } 2020 \mathrm{~b} ; \\
\text { Rahimi } \text { et al., 2020; } \\
\text { Wahedi } \text { et al., } 2020\end{array}$ \\
\hline Quercetin & $\begin{array}{l}\text { Apples, berries, brassica vegetables, } \\
\text { grapes, onions, tea and tomatoes }\end{array}$ & $\begin{array}{l}\text { Pro-metabolic, anti-inflammatory, and } \\
\text { antiviral effects }\end{array}$ & \\
\hline Resveratrol & $\begin{array}{l}\text { Grapes, berries, mulberry,peanuts, } \\
\text { and mainly red grapes/wine }\end{array}$ & $\begin{array}{l}\text { Viral RNA replication inhibition, cell death } \\
\text { reduction, inhibition of apoptosis }\end{array}$ & \\
\hline Anthocyanins & Pomegranate, berries, jamun & $\begin{array}{l}\text { Anti-inflammatory, antioxidant, antiplatelet, } \\
\text { anticarcinogenic, cardioprotective and } \\
\text { immunomodulatory }\end{array}$ & \\
\hline
\end{tabular}

\section{Conclusion}

COVID-19 a worldwide pandemic declared by WHO due to a novel virus which has grapple the world with inevitable threat to maintain good immune system as well as health, thus leads mankind to rethink about the natural remedies to improve immunity of human being through maintaining proper nutrition. Thus, maintaining good nutrition through natural bioactive compounds from natural sources has capability to provide good immunity with lower risk of viruses attack. Here is the need of functional food arises that will fulfil the requirement of dietary food functional components which helps in protecting the body from various diseases. Hence, foods having different functional components like vitamins (A, B, C, and D), minerals (selenium, zinc, and iron) and polyphenolic compounds (quercetin, resveratrol, catechins, anthocyanins) can act as natural therapeutic agents against SARS-CoV-2 or preventive therapy for COVID-19 patients besides improving immunity of the body to combat COVID-19 infection. Thus, with the increasing spread of the virus worldwide, it can be an alternate to combat COVID-19 infection with the consumption of various types of functional foods.

\section{Conflict of interest}

The authors declare that there are no conflicts of interest relevant to this article.

\section{References}

Abobaker, A.; Alzwi, A. and Alraied, A.H.A. (2020). Overview of the possible role of vitamin C in management of COVID-19. Pharmacol. Rep., 72: $1517-1528$.

Ali, N. (2020). Role of vitamin D in preventing of COVID-19 infection, progression and severity. Journal of Infection and Public Health, 13(10):1373-1380. doi: 10.1016/j.jiph.2020.06.021.
Alkhatib, A. (2020). Antiviral functional foods and exercise lifestyle prevention of Coronavirus. Nutrients, 12(9):2633. doi: 10.3390/ nu12092633.

Alkhatib, A. and Tuomilehto, J. (2019). Lifestyle diabetes prevention. In encyclopaedia of endocrine diseases (Huhtaniemi, I. and Martini, L. Eds.) Elsevier: Amsterdam, The Netherlands, pp:148-159.

Alpert, P.T. (2017). The role of vitamins and minerals on the immune system. Home Health Care Manag. Pract., 29(3):199-202.

Andreou, A.; Trantza, S.; Filippou, D.; Sipsas, N. and Tsiodras, S. (2020). COVID19: The potential role of copper and $\mathrm{N}$-acetylcysteine (NAC) in a combination of candidate antiviral treatments against SARS-CoV-2. In vivo, 34(3):1567-1588. doi:10.21873/invivo.11946.

Bae, M. and Kim, H. (2020). The role of vitamin C, vitamin D, and selenium in immune system against COVID-19. Molecules, 25:5346. doi: $10.3390 /$ molecules 25225346 .

Baeke, F.; Takiishi, T.; Korf, H.; Gysemans, C. and Mathieu, C. (2010). Vitamin D: Modulator of the immune system. Curr. Opin. Pharmacol., 10(4):482-96. doi: 10.1016/j.coph.2010.04.001.

Banerjee, A.; Kulcsar, K.; Misra, V.; Frieman, M. and Mossman, K. (2019). Bats and coronaviruses. Viruses, 11(1):41. doi:10.3390/v11010041.

Bhatt, K.; Azmat, M.; Subhan, M.; Khawaja, U.A.; Thevuthasan, S.; Mathew, A.; Khan, I.; Agadi, K.; Vazquez, Z. and Garcia, D. (2020). Role of micronutrients (Vitamins and Minerals) in COVID-19. J. Nutri. Bio., 6(1):430-443.

Bonaventura, P.; Benedetti, G.; Albarede, F. and Miossec, P. (2015). Zinc and its role in immunity and inflammation. Autoimmun. Rev., 14(4):277285. doi:10.1016/j.autre v.2014.11.008.

Budi, H.T.S.; Wintergerst, E. and Maggini, S. (2015). Multivitamin supplementation supports immune function and ameliorates conditions triggered by reduced air quality. Vitam. Min., 4(2):1-15. 
Butler, M.J.; Ruth, M. and Barrientos, R. M. (2020). The impact of nutrition on COVID-19 susceptibility and long-term consequences. Brain, Behavior and Immunity, 87:53-54.

Calder, P.C. (2020). Nutrition, immunity and COVID-19. BMJ Nutrition, Prevention and Health, doi:10.1136/bmjnph-2020-000085.

Calder, P.C.; Carr, A.C.; Gombart, A.F. and Eggersdorfer, M. (2020). Optimal nutritional status for a well-functioning immune system is an important factor to protect against viral infections. Nutrients, 12:1181.

Carr, A.C. and Maggini, S. (2017). Vitamin C and immune function. Nutrient., 9(11): 1211 . doi: $10.3390 /$ nu9111211.

Carr, A.C. and Rowe, S. (2020). The emerging role of Vitamin C in the prevention and treatment of COVID-19. Nutrients, 12(11):3286. doi:10.3390/nu12113286.

Center. M.I. (2016). Immunity in depth. Linus Pauling Institute. https :// lpi.orego nstat e.edu/mic/healt h-disea se/immunity. Accessed 3 May 2020

Chandra, R.K. and Sudhakaran, L. (1990). Regulation of immune response by vitamin B6. Ann. N. Y. Acad. Sci., 585:404-23. doi: 10.1111/j. 1749-6632.1990.tb28073.x.

Channappanavar, R. and Perlman, S. (2017). Pathogenic human coronavirus infections: Causes and consequences of cytokine storm and immunopathology. Semin Immunopathol., 39:529-39. doi:10.1007/s00281017-0629-x.

Chojnacka, K.; Witek-Krowiak,A.; Skrzypczak,D.; Mikula, K. and M³ynarz, P.(2020) Phytochemicals containing biologically active polyphenols as an effective agent against COVID-19 inducing coronavirus. J. Funct. Foods, 73:104-146.

Coelho-Ravagnani, D.F.; Corgosinho, C.; Sanches, F.C.; Prado, F.L.F.Z.; Laviano, C.M.M. and Mota, J.F. (2020). Dietary recommendations during the COVID-19 pandemic. Nutrition Reviews, 79(4):382-393. doi: $10.1093 /$ nutrit/nuaa067

Cortes, A.A. and Zuniga, J.M. (2020). The use of copper to help prevent transmission of SARS-coronavirus and influenza viruses. A general review. Diagnostic Microbiology and Infectious Disease, 98(4):115176. doi:10.1016/j.diagmicrobio.2020.115176.

Cutolo, M.; Paolino, S. and Smith, V. (2020). Evidences for a protective role of vitamin D in COVID-19. RMD Open, 6:001454. doi:10.1136/ rmdopen-2020-001454

Dehghani-Samani, A.; Kamali, M. and Hoseinzadeh-Chahkandak, F. (2020). The role of vitamins on the prevention and/or treatment of COVID-19 infection: A systematic review. Mod. Care J., 17(3):104740. doi: 10.5812/modernc. 104740 .

Dhok, A.; Butola, L.K.; Anjankar, A.; Shinde, A.D.R.S.; Kute, P.K. and Jha R.K. (2020). Role of vitamins and minerals to improve immunity during COVID-19 pandemic: A review. J. Evolution Med. Dent. Sci. 9(32):2296-2300. doi:10.14260/jemds/2020/497.

Fehr, A.R. and Perlman, S. (2015). Coronaviruses: An overview of their replication and pathogenesis. Methods Mol. Biol., 1282:1-23. doi: $10.1007 / 978-1-4939-2438-71$

Finzi, E. (2020). Treatment of SARS-CoV-2 with high dose oral zinc salts: A report on four patients. Int. J. Infect. Dis., 99:307-309. doi: 10.1016/j.ijid.2020.06.006

Fooladi, S.; Matin, S. and Mahmoodpoor, A. (2020). Copper as a potential adjunct therapy for critically ill COVID-19 patients. Clinical Nutrition ESPEN, 40:90-91

Gianchecchi, E. and Fierabracci, A. (2020). Insights on the effects of resveratrol and some of its derivatives in cancer and autoimmunity: a molecule with a dual activity. Antioxidants, 9:91
Godfrey, D.I.; Kennedy, J.; Suda, T. and Zlotnik, A. (2012). A developmental pathway involving four phenotypically and functionally distinct subsets of CD3-CD4-CD8- triple-negative adult mouse thymocytes defined by CD44 and CD25 expression. J. Immunol., 189:42034211 .

Gombart, A.F.; Pierre, A. and Maggini, S. (2020). A review of micronutrients and the immune system working in harmony to reduce the risk of infection. Nutrients, 12:236.

Grant, W.B.; Lahore, H.; McDonnell, S.L.; Baggerly, C.A.; French, C.B.; Aliano, J.L. and Bhattoa, H.P. (2020). Evidence that vitamin D supplementation could reduce risk of influenza and COVID-19 infections and deaths. Nutrients, 12:988.

Hamid; Thakur N.S.; Kumar, P. and Thakur, A. (2017). Development of syrup from mulberry (Morus alba L.) and its quality evaluation under ambient and refrigerated storage conditions. International Journal of Bioresource and Stress Management, 8(1):116-121.

Hamid; Thakur, N.S.; Thakur, A.; Sharma, C.; Bhatt, K. and Khan, A.A. (2020). Pomegranate and its wild genotypes: Nutraceutical opportunities and challenges. Ann. Phytomed., 9(1):32-43. http://dx.doi.org/ 10.21276/ap.2020.9.1.5

Hemila, H. (2016). Vitamin E administration may decrease the incidence of pneumonia in elderly males. Clin. Interv. Aging, 11:1379-1385. doi: $10.2147 /$ CIA.S114515

Huang, Z.; Liu, Y.; Qi, G.; Brand, D. and Zheng, S.G. (2018). Role of vitamin A in the immune system. Journal of Clinical Medicine., 7(9):258.

Islam, M.T.; Sarkar, C.; El-Kersh, D.M.; Jamaddar, S.; Uddin, S.J.; Shilpi, J.A. and Mubarak, M.S. (2020). Natural products and their derivatives against coronavirus: A review of the non-clinical and pre-clinical data. Phytotherapy Research, 4(10):2471-2492. doi: /10.1002/ptr.6700.

Junaid, K.; Ejaz, H.; Abdalla, A.E.; Abosalif, K.O.A.; Ullah, M.I.; Yasmeen, H.; Younas, S.; Hamam, S.S.M. and Rehman, A. (2020). Effective immune functions of micronutrients against SARS-CoV-2. Nutrients, 12(10): 2992.

Kaihatsu, K.; Yamabe, M. and Ebara, Y. (2018). Antiviral mechanism of action of epigallocatechin- 3-O-gallate and its fatty acid esters. Molecules, 23:2475. doi: 10.3390/molecules23102475.

Kamboj, A.; Saluja, A.K.; Kumar, M. and Atri, P. (2012). Antiviral activity of plant polyphenols. Journal of Pharmacy Research, 5(5):2402-2412.

Kashyap, P.; Anand, S. and Thakur, A. (2017). Evaluation of antioxidant and antimicrobial activity of Rhododendron arboreum flowers extract. Int. J. Food Ferment. Tech., 7(1):123-128. https://www.doi.org/ 10.5958/2277-9396.2017.00013.7

Khalil, A. and Tazeddinova, D. (2020). The upshot of Polyphenolic compounds on immunity amid COVID-19 pandemic and other emerging communicable diseases: An appraisal. Nat. Prod. Bioprospect., 10:411-429. doi: 10.1007/s13659-020-00271-z

Kieliszek, M. and Lipinski, B. (2020). Selenium supplementation in the prevention of coronavirus infections (COVID-19). Medical Hypotheses, 143:109878. doi: 10.1016/j.mehy.2020.109878

Kumar, V. and Choudhry, V.P. (2010). Iron deficiency and infection. Indian J. Pediatr., 77(7):789-93

Lauer, S.; Grantz, K.; Bi, Q. and Jones, F. (2020). The incubation period of coronavirus disease 2019 (COVID-19) from publicly reported confirmed cases: Estimation and application. Ann. Intern. Med., 173:577-582. doi:10.7326/M20-0504.

Laviano, A.; Koverech, A. and Zanetti, M. (2020). Nutrition support in the time of SARS-CoV-2 (COVID-19). Nutrition, 74:110834. 
Lee, G.Y. and Han, S.N. (2018). The role of vitamin E in immunity. Nutrients, 10(11):1614. doi: 10.3390/nu101 11614.

Lei, S.; Jiang, F.; Su, W.; Chen, C.; Chen, J.; Mei,W.; Zhan, L.Y.; Jia, Y.; Zhang, L.; Liu, D.; Xia, ZY. and Xia, Z. (2020). Clinical characteristics and outcomes of patients undergoing surgeries during the incubation period of COVID19 infection. E Clinical Medicine, 21:100331. doi:10.1016/ j.eclinm.2020.100331.

Levy, E.; Delvin, E.; Marcil, V. and Spahis, S. (2020). Can phytotherapy with polyphenols serve as a powerful approach for the prevention and therapy tool of novel coronavirus disease 2019 (COVID-19)?. Am. J. Physiol. Endocrinol. Metab., 319:689-708. doi:10.1152/ajpendo. 00298.2020 .

Li, H.; Liu, S.M.; Yu, X.H.; Tang, S.L. and Tang, C.K. (2020a). Coronavirus disease 2019 (COVID-19): Current status and future perspectives. International Journal of Antimicrobial Agent, 55(5):105-951. doi: 10.1016/j.ijantimicag.2020.105951.

Li, D.; Zhang, T.; Lu, J.; Peng, C. and Lin, L. (2020b). Natural constituents from food sources as therapeutic agents for obesity and metabolic diseases targeting adipose tissue inflammation. Crit. Rev. Food Sci. Nutr., 28:1-19. doi:10.1080/10408398.2020.1768044.

Lin, S.C.; Ho, C.T.; Chuo, W.H.; Li, S.; Wang, T.T. and Lin, C.C. (2017). Effective inhibition of MERS-CoV infection by resveratrol. BMC Infect. Dis., 17:144. doi: 10.1186/s 12879-017-2253-8.

Liu, W.; Zhang, S.; Nekhai, S. and Liu S. (2020). Depriving iron supply to the virus represents a promising adjuvant therapeutic against viral survival. Curr. Clin. Micro. Rpt., 7:13-19.

Lopez-Varela, S.; Gonzalez-Gross, M. and Marcos, A. (2002). Functional foods and the immune system: a review. Eur. J. Clin. Nutr., 56:29-33. doi: org/10.1038/sj.ejcn.1601481.

Maares, M. and Haase, H. (2016). Zinc and immunity: An essential interrelation. Arch Biochem Biophys., 611:58-65. doi: 10.1016/ j.abb.2016.03.022.

Maggini, S.; Wintergerst, E.S.; Beveridge, S. and Hornig, D.H. (2007). Selected vitamins and trace elements support immune function by strengthening epithelial barriers and cellular and humoral immune responses. British Journal of Nutrition, 98(1):29-35.

Maggini, S.B.S.; Sorbara, J.P. and Senatore, G. (2018). Feeding the immune system: the role of micronutrients in restoring resistance to infections. Cab Rev. Perspect. Agric. Vet. Sci. Nutr. Nat. Resour., 3:1-21. doi:10.1079/PAVSN NR200 8309.

Mahalanabis, D.; Lahiri, M.; Paul, D.; Gupta, S.; Gupta,A.; Wahed, M.A. and Khaled, M.A. (2004). Randomized, double-blind, placebocontrolled clinical trial of the efficacy of treatment with zinc or vitamin A in infants and young children with severe acute lower respiratory infection. Am. J. Clin. Nutr., 79(3):430-436. doi: 10.1093/ajcn/79.3.430

Martineau, A.R.; Jolliffe, D.A.; Greenberg, L.; Aloia, J.F.; Bergman, P.; DubnovRaz, G.; Esposito, S.; Ganmaa, D.; Ginde, A.A.; Goodall, E.C.; Grant, C.C.; Janssens, W.; Jensen, M.E.; Kerley, C.P.; Laaksi, I.; Holland, S.M.; Mauger, D.; Murdoch, D.R.; Neale, R.; Rees, J.R.; Simpson, S.; Stelmach, I.; Kumar, G.T.; Urashima, M.; Camargo, C.A.; Griffiths, C.J. and Hooper, R. (2019). Vitamin D supplementation to prevent acute respiratory infections: Individual participant data meta-analysis. Health Technol. Assess., 23:1-44. doi: $10.3310 /$ hta23020.

Martirosyan, D. (2020). The emerging potential of functional foods in viral disease prevention. Functional Foods in Health and Disease, 6(10):95-99.

Martirosyan, D.M. and Singh, J. (2015). A new definition of functional food by FFC: What makes a new definition unique? Funct. Foods Health Dis., 5:209-223.
Medrano, M.; Carrillo-Cruz, E.; Montero, I. and Perez-Simon, J.A. (2018). Vitamin D: Effect on Haematopoiesis and Immune System and Clinical Applications. Int. J. Mol. Sci., 19:2663. doi:10.3390/ijms190926 63

Meisel, E.; Efros, O.; Bleier, J.; Beit Halevi, T.; Segal, G.; Rahav, G.; Leibowitz, A. and Grossman, E. (2021). Folate Levels in Patients Hospitalized with Coronavirus Disease 2019. Nutrient., 13:812. doi:10.3390/nu1303 0812 .

McKenzie, R.C.; Arthur, J.R. and Beckett, G.J. (2002). Selenium and the regulation of cell signalling, growth and survival: Molecular and mechanistic aspects. Antioxidants and Redox Signaling, 4(2):339351.

Meydani, S.N.; Ribaya-Mercado, J.D.; Russell, R.M.; Sahyoun, N.; Morrow, F.D. and Gershoff, S.N. (1991). Vitamin B-6 deficiency impairs interleukin 2 production and lymphocyte proliferation in elderly adults. Am. J. Clin. Nutr., 53(5):1275-1280. doi: 10.1093/ajen/53.5.1275.

Michele, C.A.; Angel, B.; Valeria, L.; Teresa, M.; Giuseppe, C.; Giovanni, M.; Ernestina, P. and Mario, B. (2020). Vitamin supplements in the era of SARS-Cov-2 pandemic. GSC Biol. Pharm. Sci., 11(2):07-19.

Mikkelsen, K.; Stojanovska, L.; Prakash, M. and Apostolopoulos, V. (2017). The effects of vitamin B on the immune/cytokine network and their involvement in depression. Maturitas, 96:58-71. doi: 10.1016/ j.maturitas.2016.11.012.

Moghaddam,A.; Heller, R.A.; Sun, Q.; Seelig, J.; Cherkezov,A.; Seibert, L.; Hackler, J.; Seemann, P.; Diegmann, J.; Pilz, M.; Bachmann, M., Minich, W.B. and Schomburg, L. (2020). Selenium deficiency is associated with mortality risk from COVID-19. Nutrients, 12:2098. doi: 10.3390/nu 12072098.

Monacelli, F.; Acquarone, E.; Giannotti, C.; Borghi, R. and Nencioni, A. (2017). Vitamin C, aging and Alzheimer's disease. Nutrients, 9:670. doi:10.3390/nu9070670 doi:10.3390/nu907 0670 .

Moriguchi, S. and Muraga, E. (2000). Vitamin E and immunity. Vitam. Horm., 59:305-336.

Mousavi, S.; Bereswill, S. and Heimesaat, M.M. (2019). Immunomodulatory and antimicrobial effects of vitamin C. Eur. J. Microbiol. Immunol., 9(3):73-79. doi: 10.1556/1886.2019.00016

Perricone, C.; Bartoloni, E.; Bursi, R.; Cafaro, G.; Guidelli, G.M.; Shoenfeld, Y. and Gerl, R. (2020). COVID-19 as part of the hyperferritinemic syndromes: the role of iron depletion therapy. Immunol. Res., 68:213-224. doi: 10.1007/s12026-020-09145-5

Prasad, A.S. (2009). Zinc: role in immunity, oxidative stress and chronic inflammation. Current opinion in clinical nutrition and Metabolic Care, 12:646-652.

Quiros-Sauceda, A.E.; Palafox-Carlos, H.; Sayago-Ayerdi, S.G.; Ayala-Zavala, J.F.; Bello-Perez, L.A.; Alvarez-Parrilla, E.; De La Rosa, L.A.; GonzalezCordova, A.F. and González-Aguilar, G.A. (2014). Dietary fiber and phenolic compounds as functional ingredients: Interaction and possible effect after ingestion. Food Funct., 5:1063-1072.

Raha, S.; Mallick, R.; Basak, S. and Duttaroy, A.K. (2020). Is copper beneficial for COVID-19 patients?. Med. Hypotheses, 142:109814. doi: 10.1016/j.mehy.2020.109814

Rahimi, K.; Hassanzadeh, K.; Khanbabaei, H.; Haftcheshmeh, S.M.; Ahmadi, A.; Izadpanah, E.; Mohammadi, A. and Sahebkar, A. (2020). Curcumin: a dietary phytochemical for targeting the phenotype and function of dendritic cells. Curr. Med. Chem., doi: 10.2174/ 0929867327666200 515101228 .

Rathinavel, T.; Meganathan, B.; Kumarasamy, S.; Ammashi, S.; Thangaswamy, S.; Ragunathan, Y. and Palanisamy, S. (2020). Potential COVID-19 drug from natural phenolic compounds through in silico virtual screening approach. Biointerface Research in Applied Chemistry, 11(3): 10161-10173. 
Ross, A.C. (1996). Vitamin A deficiency and retinoid repletion regulate the antibody response to bacterial antigens and the maintenance of natural killer cells. Clin. Immunol. Immunopathol., 80:63-72. doi: 10.1006/clin.1996.0143.

Saeed, F.N.M.; Ahmed, R.; Nadeem, M.K.; Arshad, M.S. and Ullah, A. (2016). Studying the impact of nutritional immunology underlying the modulation of immune responses by nutritional compounds: A review. Food Agric. Immunol., 27:205-229. doi: 10.1080/ 09540105.2015 .1079600

Saleem, M.; Ahmed, M.; Abro, A.A. and Chen, G. (2021). COVID-19 and its Spread. European Academic Research, 9(1):449-456.

Santos, L.M.J.D. (2020). Can vitamin B $_{12}$ be an adjuvant to COVID-19 treatment? GSC Biol. Pharm. Sci., 11(3):1-5.

Sayed, A.M.; Khattab, A.R.; AboulMagd, A.M.; Hassan, H.M.; Rateb, M.E.; Zaid,H and Abdelmohsen, U.R. (2020). Nature as a treasure trove of potential anti SARS-CoV drug leads: a structural/mechanistic rationale. RSC Advances, 10:19790-19802. doi:10.1039/D0RA04199H

Seyed, H.E.; Riahi, K.N.; Nikzad, H.; Azadbakht, J.; Hassani, B.H. and Haddad, K.H. (2020). The novel coronavirus Disease-2019 (COVID-19): mechanism of action, detection and recent therapeutic strategies. Virology, 551:1-9. doi:10.1016/j.virol.2020.08.011.

Shakoor, H.; Feehan, J.; Mikkelsen, K.; Al Dhaheri,A.S.; Ali, H.I.; Platat, C.; Ismail, L.C.; Stojanovska, L. and Apostolopoulos, V. (2021). Be well: A potential role for vitamin B in COVID-19. Maturitas, 144:108-111. doi: 10.1016/j.maturitas.2020.08.007

Sharma, R.; Choudhary, R., Thakur, N.S. and Thakur, A. (2019). Developmen and quality of apple-whey based herbal functional ready-to-serve beverage. Journal of Applied and Natural Science, 11(2):291-298. doi: $10.31018 /$ jans.v11i2.2047.

Sharma, R.; Choudhary, R., Thakur, N.S.; Bishist, R. and Thakur, A. (2020) Optimization of fructooligosaccharide fortified low calorie applewhey based RTS beverage and its quality evaluation during storage. Current Journal of Applied Science and Technology, 39(10):17-28. https://doi.org/10.9734/CJAST/2020/v39i1030625.

Sheybani, Z.; Maryam, H.D.; Manica, N.; Mehdi, D.; Hassan, Z.; Mohsen, M.; Seyed, M.M. and Amin, R.Z. (2020). The role of folic acid in the management of respiratory disease caused by COVID-19. Chem Rxiv, doi: 10.26434/chemrxiv.12034980.v1

Singh, P.; Tripathi, M.K.; Yasir, M.; Khare, R.; Tripathi, M.K. and Shrivastva, R. (2020). Potential Inhibitors for SARS-CoV-2 and Functional Food Components as Nutritional Supplement for COVID-19: A Review. Plant Foods Hum. Nutr., 75:458-466. doi: 10.1007/s11130-02000861-9.

Singhal, T. (2020). A review of coronavirus disease-2019 (COVID-19). Indian J. Pediatr., 87(4):281-286.

Tanumihardjo, S.A.; Russell, R.M.; Stephensen, C.B.; Gannon, B.M.; Craft, N.E.; Haskell, M.J.; Lietz, G.; Schulze, K. and Raiten, D.J. (2016). Biomarkers of nutrition for development (BOND)-vitamin A review. J. Nutr., 146(9):1816-1848. doi: 10.3945/jn. 115.229708.
Thakur, A.; Joshi, V.K. and Thakur, N.S. (2019). Immunology and its relation with food components: an overview. International Journal of Food and Fermentation Technology, 9(1):1-16. doi:10.30954/22779396.01.2019.3.

Thakur, N.S.; Thakur, A.; Joshi, V.K. and Sharma, S.K. (2018). Botrytized wines: A review. International Journal of Food and Fermentation Technology, 8(1):1-13. doi:10.30954/2277-9396.01.2018.1.

Thakur, A.; Thakur, N.S.; Hamid, and Gautam, S. (2020). Effect of packaging on phenols, flavonoids and antioxidant activity of dried wild pomegranate (Punica granatum L.) arils prepared in solar tunnel drier. Annals of Phytomedicine, 9(2):198-206. doi: 10.21276/ ap.2020.9.2.17.

Villamor, E. and Fawzi, W.W. (2005). Effects of vitamin a supplementation on immune responses and correlation with clinical outcomes. Clinical Microbiology Reviews, 18(3):446-464.

Villar, J.; Zhang, H. and Slutsky, A.S. (2019). Lung repair and regeneration in ARDS: role of PECAM1 and Wnt signaling. Chest., 155:587-94. doi: 10.1016/j.chest.2018.10.022.

Wahedi, H.M.; Ahmad, S. and Abbasi, S.W. (2020). Stilbene-based natural compounds as promising drug candidates against COVID-19. J. Biomol. Struct. Dyn., 12:1-10. doi:10.1080/07391102.2020.1762743.

Wan-Fei, L.; Chik, W.I.; Dong-Ying, W. and Lu-Tai, P. (2017). Plant phenolic compounds as potential lead compounds in functional foods for antiviral drug discovery, Curr. Org. Chem., 21:1847-1860.

Wang, H. and Ma, S. (2008). The cytokine storm and factors determining the sequence and severity of organ dysfunction in multiple organ dysfunction syndrome. Am. J. Emerg. Med., 26:711-15. doi: 10.1016/j.ajem.2007.10.031

Wu, D.; Lewis, E.D.; Pae, M. and Meydani, S.N. (2018). Nutritional modulation of immune function: analysis of evidence, mechanisms, and clinical relevance. Front. Immunol., 9:3160. doi: 10.3389/fimmu. 2018. 03160 .

Yahfoufi, N.; Alsadi, N.; Jambi, M. and Matar, C. (2018). The immunomodulatory and anti-inflammatory role of polyphenols. Nutrients, 10:1618. doi: $10.3390 /$ nu 10111618 .

Yang, D. and Leibowitz, J.L. (2015). The structure and functions of coronavirus genomic 3 and 5 ends. Virus Res., 206:120-33. doi:10.1016/ j.virusres.2015.02.025.

Yang, F.; Zhang, Y.; Tariq, A.; Jiang, X.; Ahmed, Z; Zhihao, Z.; Idrees, M.; Azizullah, A.; Adnan, M. and Bussmann, R.W. (2020). Food as medicine: a possible preventive measure against coronavirus disease (COVID-19). Phytother. Res., 34:1-13, doi:10.1002/ptr.6770.

Zhang, J.; Taylor, E.W.; Bennett, K.; Saad, R. and Rayman, M.P. (2020). Association between regional selenium status and reported outcome of COVID19 cases in China. Am. J. Clin. Nutr., 111:1297-1299.

Zhang, L. and Liu, Y. (2020). Potential interventions for novel coronavirus in China: a systematic review. J. Med. Virol., 92(5):479-490. doi: 10.1002/jmv.25707. 